О.П. ДОМБРОВСЬКА, Л.А. ЧУРСІНА, О.М. МАНДРА

Херсонський національний технічний університет

\title{
АКТУАЛЬНІСТЬ ДОСЛІДЖЕННЯ СПОЖИВНИХ ХАРАКТЕРИСТИК КОНОПЛЯНИХ ВИРОБІВ, ОДЕРЖАНИХ ЗА ІННОВАЦІЙНИМИ ТЕХНОЛОГІЯМИ
}

\author{
O.P. DOMBROVSKA, L.A. CHURSINA,O.M. MANDRA
}

Kherson national technical university

\section{RELEVANCE OF RESEARCH OF CONSUMER CHARACTERISTICS OF HEMP PRODUCTS OBTAINED BY INNOVATIVE TECHNOLOGIES}

\section{https://doi.org/10.36910/6775-2310-5283-2021-14-17}

Мета. Метою є вивчення споживних характеристик конопляних виробів,одержаних за інноваційними технологіями. Розробиі нових способів отримання конопляних виробів за інновачійними технологіями приділяється значна увага в усьому світі. В роботі доведено, щзо розширення системи оцінки якості споживних характеристик нових виробів, одержаних зі стебел та насіння конопель, щуо отримуються за інноваційними технологіями $\epsilon$ актуальним питанням.

Методика. Під час дослідження використовували передбачені діючими стандартами методи. Огляд джерел технічної та товарознавчої літератури здійснювали за допомогою інформаційно-аналітичних методів порівняльного та системного аналізу.

Результати. У статті представлено аналіз існуючого стану переробки стебел $i$ насіння конопель в різних країнах світу. Проведено аналіз якості одержаних виробів за різними технологіями. Встановлено, щзо в Україні, не дивлячись на підвищення технологічної активності виробників конопляного волокна $i$ насіння, майже повністю відсутнє товарознавче оцінювання якісних властивостей одержуваних нових виробів, які впливають на організм людини. В роботі наведено оцінку товарознавчих характеристик конопляної продукиії на основі існуючої нормативної бази та визначені завдання з розширення изієї оцінки в залежності від функиіонального призначення інноваційних виробів.

Особливої уваги потребують дослідження санітарно-гігієнічних властивостей, антисептичних характеристик виробів із конопель, оскільки нормативні документи для їх визначення відсутні. Все ие є підгрунтям для подальших досліджень. В перспективі будуть досліджені споживні характеристики з урахуванням санітарно-гігієнічних, антисептичних, фізико-механічних властивостей та енергетичної й лікувальної цінності харчових продуктів з конопель. 
Наукова новизна. В роботі виокремлено існуючу систему оцінки якості конопляних виробів на основі застарілої нормативної бази. Показники якості, за якими здійснюється сучасна характеристика конопляних виробів, не відображають функиіональне призначення інноваційних товарів із стебел та насіння конопель, у зв'язку з иим не можуть бути використані для визначення їх конкурентоздатності на вітчизняному та світовому ринках. Тому, на основі проведеного аналізу, в роботі доведена необхідність розширення системи показників якості конопляних виробів, які враховували б вплив їх на організм людини, тобто санітарно-гігієнічні, антисептичні, біологічні властивості, а також енергетичну та лікувальну цінність харчових продуктів із конопель.

Практична значимість. Запропоновані дослідження можуть бути використані для створення нормативних документів на конопляні волокна, отримані за інновачійними технологіями. Отримані результати досліджень можуть бути використані при виявленні фальсифікованих конопляних товарів, щзо перетинають кордон Украйни.

Ключові слова. Конопляні вироби, інноваційні технології, споживні властивості, санітарно - гігієнічні властивості, антисептичні характеристики.

Постановка проблеми у загальному вигляді та її зв'язок із важливими науковими чи практичними завданнями. В останні роки у світі та в нашій країні суттєво зросли обсяги вирощування технічних конопель. У той же час, попит на продукцію з технічних конопель постійно зростає: за останні 10 років світовий ринок ненаркотичних конопель піднявся «з нуля» до кількох сотень мільярдів доларів. На сьогодні промислова конопля $є$ однією 3 сільськогосподарських культур, яка найбільш повно відповідає стратегічним цілям i завданням державної екологічної політики України до 2030 p ., затвердженої Законом України від 28 лютого 2019 №2697-VIII [1].

Коноплі - це поновлюваний ресурс, який росте швидше i легше, ніж дерева. Це робить дану рослину більш рентабельною. Адже для використання дерев потрібно очікувати десятиліття, коли дерева виростуть. Кора стебла конопель містить луб'яні волокна, які $є$ одними 3 найдовших натуральних м'яких волокон на землі, а також багаті на целюлозу.

Широкий асортимент конопляних виробів, представлений на світовому ринку, не завжди характеризується відповідними споживними показниками. Тому питання дослідження якості конопляних виробів є актуальним.

Аналіз останніх досліджень, у яких започатковано вирішення проблеми. Вивченням властивостей конопель як лубоволокнистої сировини, а також розробкою та удосконаленням технологій та способів переробки займалися багато вітчизняних вчених, працюючих в основному в Інституті луб’яних культур НААН, а також багато закордонних дослідників. Найбільш 
відомі роботи: Мохера Ю.В., Коробченко С.П., Марінченко І.О., Ляліної Н.П., А.В. Безбабченко, Є.В. Новікова, Пашина Є.Л., Ордіної Н.А., Л.А. Хейфица, К.Буйона, Д. Кларка та інших [2-8].

Але в цих роботах в основному приділялася увага новим способам обробки сировини, створенню нових пристроїв, технологічних процесів та обладнання 3 переробки конопель, тоді як споживні характеристики продукції, одержаної 3 волокна i насіння конопель за інноваційними технологіями майже не досліджені. Адже саме від них залежить вихід інноваційних конопляних продуктів на світовий ринок.

На нашу думку, косметичні товари, продукти харчування та інші інноваційні вироби 3 конопель відносяться до особливої групи товарів, споживні характеристики яких потребують більш детального вивчення, оскільки вони безпосередньо використовуються в побуті та харчуванні. Ще одним важливим аспектом необхідності оцінювання якості та безпечності конопляних товарів $\epsilon$ той факт, що на ці характеристики відсутня нормативна база, яка може гарантувати конкурентоздатність конопляних виробів на вітчизняному та світовому ринках.

Тому питання дослідження якості та безпечності конопляних товарів $\epsilon$ сучасним та актуальним.

Цілі статті. Метою роботи є аналіз споживних характеристик конопляних виробів, які на даний час присутні на вітчизняному ринку.

Об'єкт дослідження. Конопляні вироби різних виробників.

Методи дослідження. Під час дослідження використовували передбачені діючими стандартами методи. Огляд джерел технічної та товарознавчої літератури здійснювали за допомогою інформаційно-аналітичних методів порівняльного та системного аналізу.

Виклад основного матеріалу дослідження 3 повним обгрунтуванням отриманих наукових результатів. Коноплі вирощуються в таких країнах, як Канада, США, Франція, Угорщина, Бельгія, Голландія, Таїланд, Австрія, Італія, Китай, Філіппіни, Росія, Мексика, Німеччина, Індія.

В даний час велика частина вітчизняного попиту на текстиль задовольняється за рахунок бавовни і синтетики, застосування яких пов'язані 3 серйозними екологічними проблемами.

Волокно конопель довше (табл.1), міцніше, краще вбирає вологу, стійкіше до грибкових заражень,має високу термопровідність, ніж волокно бавовни. 
Папір, виготовлений з конопель, міцніший і дешевший у виробництві, ніж папір 3 деревини. 3 гектара конопель можна виробити стільки ж паперу, як 3 чотирьох гектарів лісу. При цьому коноплі ростуть набагато швидше, ніж дерева: 120 днів замість 20 років [9].

Таблиця 1. Порівняльні фізико-механічні властивості волокна конопель та бавовни[10]

\begin{tabular}{|l|c|c|}
\hline \multicolumn{1}{|c|}{ Найменування характеристик } & Коноплі & Бавовна \\
\hline \multicolumn{1}{|c|}{ Довжина технічного волокна, мм } & $700-1500$ & - \\
\hline Лінійна щільність технічних волокон, текс & $8-40$ & - \\
\hline Середня довжина елементарних волокон, мм & $15-25$ & $22-45$ \\
\hline Макс. Довжина елементарних волокон, мм & 65 & 45 \\
\hline $\begin{array}{l}\text { Розмір поперечного перерізу елементарних } \\
\text { волокон, мкм }\end{array}$ & $14-50$ & $1-2$ \\
\hline Середня лінійна щільність елементарних волокон, мтекс & $220-440$ & $130-220$ \\
\hline Питома вага, г/см & & $1,47-1,5$ \\
\hline $\begin{array}{l}\text { Показник товщини, } \\
\text { мм }\end{array}$ & $1,48-1,5$ & $0,09-$ \\
\hline $\begin{array}{l}\text { Середній коефіцієнт } \\
\text { прозенхімності }\end{array}$ & $0,13-0,29$ & - \\
\hline $\begin{array}{l}\text { Середнє подовження при розриві, } \\
\text { \% }\end{array}$ & $600-1000$ & $6,9-7,2$ \\
\hline $\begin{array}{l}\text { Вологість волокна, \% } \\
\text { при відносній вологості 60 \% } \\
\text { при відносній вологості 90 \% }\end{array}$ & $2,2-3,0$ & 8,0 \\
\hline
\end{tabular}

Коноплі вирощують понад 30 країн, при цьому Китай є найбільшим виробником i експортером конопель. Свропа i Канада також є важливими гравцями на світовому ринку конопель. Традиційно коноплі як волокно використовувалися для виробництва одягу, тканин, паперу, мотузок i будівельних матеріалів.

За оцінками експертів, світовий ринок конопель налічує понад 25000 найменувань продукції. В даний час основними ринками $є$ будівельні та ізоляційні матеріали, целюлоза, папір, текстильні та трикотажні вироби, а також продукти харчування, тоді як косметичні засоби і деталі до автомобілів $\epsilon$ зростаючими ринками. 3 80-тих років минулого століття компанії Audi, BMW, Mercedes-Benz, Fiat, Ford використовують конопляні композити для виготовлення деталей автомобілів [11].

3 конопель у світі також виготовляють одяг, алкогольні вироби, продукти харчування, пластик, парфуми, косметику, олію, солодощі (рис.1). 


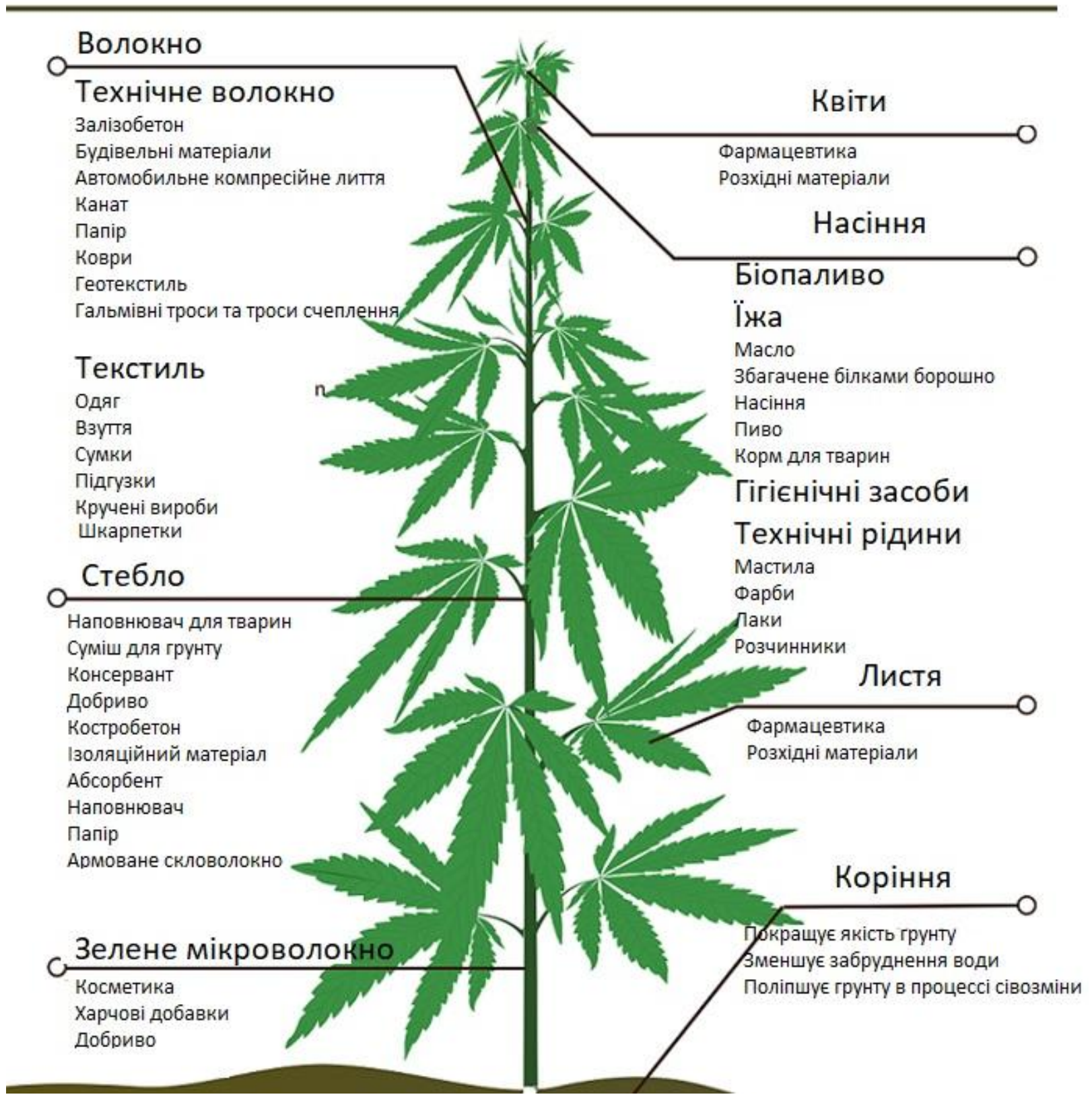

\section{Рис. 1. Сучасне використання конопель}

Інноваційні програми, наприклад, в області медицини i терапії, космецевтики, фіторемедіаціi, акустики, очищення стічних вод, біопалива, біопестицидів і біотехнології створюють нові проблеми 3 оцінювання якості нових товарів. Коноплі також $€$ об'єктом численних фундаментальних досліджень в області функціонального харчування та екологічних текстильних матеріалів [12]. 
Основна продукція Євросоюзу - це харчові та кормові продукти 3 конопель, насіння, фармацевтичні препарати, але головне - волокно. Свропейські країни, і більш за все Франція і Фінляндія, традиційно використовують волокно в будівельній і текстильній галузях.

За 25 років ринок конопляного волокна розвинувся, збільшившись на більш ніж 500\%, з яких 250\% припадають на останні вісім років. Тільки в одній Франції виробництво промислового волокна з конопель зросла 34 тис. т. у 2003 р. до більш ніж 50 тис. т. в 2019 році. Якщо розглядати ринок асортименту товарів $з$ технічних конопель, то лідером є Китай, який контролює 79-80\% всього світового виробництва конопляних товарів. У Свропі провідними державами з переробки конопель є Франція, Великобританія й Німеччина [13].

В Україні теж $є$ успішні приклади використання продуктів переробки луб’яних культур. Наприклад, у будівництві автодороги «Київ-Одеса» використовують геотекстиль для укріплення автошляхів. Таких прикладів може бути значно більше. Але розвиток галузі складний i потребує великих фінансових витрат для відродження виробництва.

В Україні законодавчо дозволено вирощувати технічну коноплю з вмістом психоактивного компоненту ТГК до 0,08\%. Для порівняння: у СС дозволений рівень ТГК у промислових коноплях становить 0,2\%, у США, Канаді та Китаї 0,3\%. Це значно вище від наших 0,08\%.

Через занадто низький дозволений вміст ТГК українські аграрії 3 вирощування та переробки конопель не можуть повноцінно конкурувати на міжнародному ринку, оскільки не мають права використовувати більшість сортів технічної коноплі, зареєстрованих у світі.

Середня врожайність дозволених культур технічної коноплі в Україні становить 7 тонни з га, а дозволених культур у Франції та Нідерландах - 10тонн з га. В Україні у 2019 році площа під посівами технічної коноплі становила 2-4 тис га, у Франції - 14,5 тис га, у Канаді - 37 тис га. У США - 60 тис га, тобто в 30 разів більше, ніж в Україні (рис.2). Окрім контролю за вмістом ТГК в Україні є низка інших регуляторних навантажень на бізнес, що унеможливлює вирощування технічної коноплі. Вирощування конопель контролюють одночасно МВС, Держлікслужба та Міністерство охорони здоров'я [14].

За останні три-чотири роки в Україні зросла велика кількість малих підприємств, які виготовляють 3 конопель буквально все - від продуктів харчування і косметики до будівельних матеріалів. 


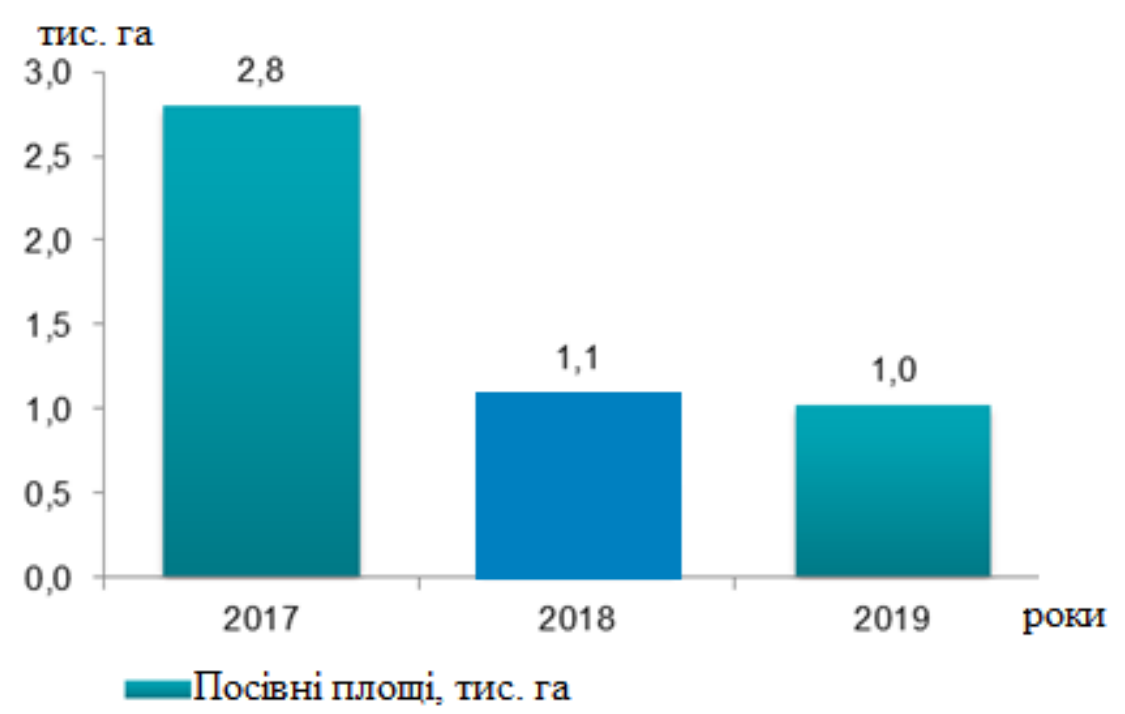

Рис.2. Динаміка посівних площ технічних конопель в Україні (20172019 рр.), тис. га[15]

Все більш популярним також стає взуття й одяг з конопель: їх виробляють в Житомирській області та в Києві (табл.2).

Таблиця 2. Основні підприсмства в Україні переробки конопляної сировини[16]

\begin{tabular}{|l|l|l|}
\hline \multicolumn{1}{|c|}{ Регіон } & \multicolumn{1}{|c|}{ Підприємства } & \multicolumn{1}{c|}{ Вид товару } \\
\hline м. Житомир & ПП Нетрs & Текстильні вироби \\
\hline м. Київ & ПП AlenGroup & $\begin{array}{l}\text { Текстильні вироби, } \\
\text { аксесуари }\end{array}$ \\
\hline м. Київ & ПП «ХэмпаерМікс» & Теплоізоляційні матеріали \\
\hline Київська обл. & ФГ «Кравець О. П.» & Олія, продукти харчування \\
\hline Полтавська обл. & ТОВ «Агро-Ханф» & Текстильні вироби,аксесуари \\
\hline Сумська обл. & ТОВ «Еліфібр» & Насіння,олія \\
\hline Сумська обл. & $\begin{array}{l}\text { Марбутська шпагатна } \\
\text { фабрика }\end{array}$ & Кручені вироби \\
\hline м. Харків & Харківський канатний завод & Кручені вироби \\
\hline
\end{tabular}

Найбільш відомий в нашій країні бренд DevoHome Оксани Дево, яка 3 2014 р створює в Україні текстильні товари з конопель. Основна продукція ковдри, подушки, покривала, постільна білизна.

Харківське ПАТ «Хімфармзавод «Червона зірка» випускає на основі конопель препарат для поліпшення сну, компанія «Екосвіт» - протеїн з насіння конопель, компанія Galka - мелену каву з додаванням конопель[17]. 
Також відомі розробки використання насіння конопель для створення так званої «суперїжі» - «суперфудів».

Ці харчові оздоровчі продукти за рахунок вмісту ненасичених жирних кислот (Омега-3, -6,-9) незамінних амінокислот, клітковини, вітамінів, макрота мікронутрієнтів відносять до їжі для здорового харчування людини [18].

Однак, дотепер в Україні відсутні дослідження показників якості даної продукції та нормативна документація для їх визначення. Як правило, якість «суперфудів» оцінюють за технічними умовами, що розробляє сам виробник.

Волокниста продукція конопель у товарообігу представлена вихідною сировиною - соломою, напівфабрикатами - лубом і трестою, одержаними на окремих стадіях переробки цієї сировини та готовим продуктом - довгим тіпаним волокном. Крім того, на ринку фігурують відходи первинної переробки - коротке волокно й угари (рис. 3) [19].

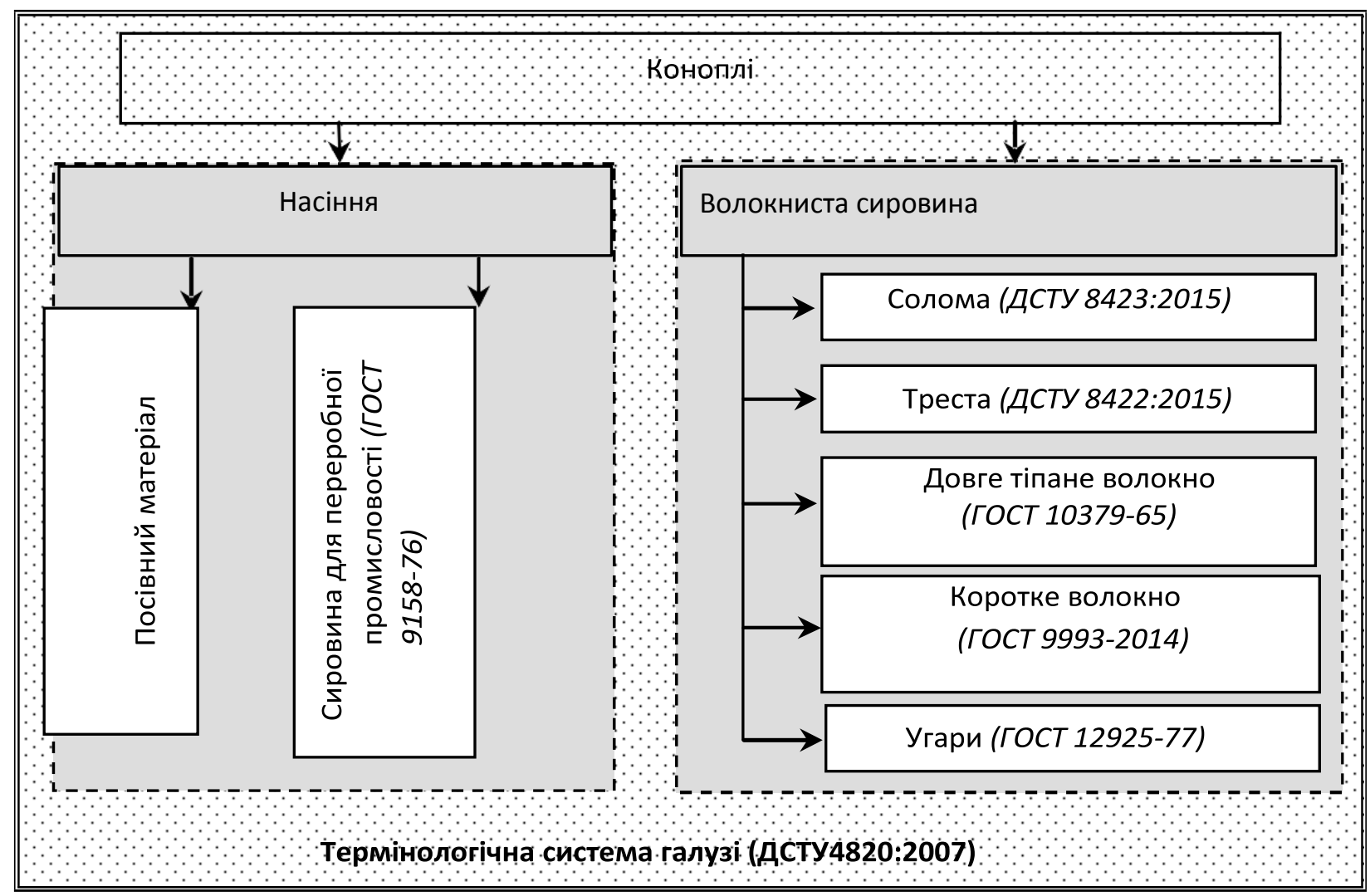

Рис.3. Нормативні документи з оцінки якості стебел і насіння *

* Перероблено авторами з урахуванням нових стандартів

Наразі товарний сорт (номер) волокнистої продукції встановлюють за наступними показниками якості: солома (ДСТУ 8423:2015) - довжина (см), 
діаметр (мм), вміст лубу ( \%), міцність лубу (Н); треста (ДСТУ 8422:2015) довжина від прикореневої частини до центра ваги (см), довжина (см), діаметр (мм), вихід волокна (\%), міцність (Н), ступінь оброблюваності; пенька тіпана (ГОСТ 10379-76) - міцність (Н), розривне навантаження (cН/волокно), лінійна щільність (текс), вміст костри (\%), вміст лапи (\%), вміст лико подібних пасм (\%), довжина жмені (см); пенька коротка (ГОСТ 9993-2014) - міцність скрученої стрічки (Н), вміст костриці (\%), масова частка лапи (\%).

Інноваційних технологій, які впливають на якість отриманої продукції багато, а методик для визначення якості одержаних нових виробів недостатньо. Основна частина нормативних документів згрупована навколо товарів, що виробляються - волокна i насіння. Однак, для розвитку конопляної промисловості необхідним постає питання не лише гармонізації існуючої нормативної бази, а й дослідження додаткових споживних властивостей інноваційних продуктів 3 конопель для контролю їх якості, що призведе до можливості використання цієї продукції не тільки на вітчизняних, але й на європейських ринках.

За результатами проведених досліджень було встановлено, що споживні характеристики, які регламентовані існуючими нормативними документами, характеризують лише фізико-механічні властивості волокон (табл. 3).

Таблиця 3.Властивості конопляної волокнистої сировини, що регламентовані національними нормативними документами

\begin{tabular}{|l|l|l|l|}
\hline $\begin{array}{l}\text { № } \\
3 / \text { п }\end{array}$ & \multicolumn{1}{|c|}{$\begin{array}{c}\text { Найменування } \\
\text { сировинного } \\
\text { матеріалу }\end{array}$} & \multicolumn{1}{|c|}{$\begin{array}{c}\text { Нормативні } \\
\text { документи }\end{array}$} & \multicolumn{1}{|c|}{ Показники якості } \\
\hline 1. & солома & $\begin{array}{l}\text { ДСТУ 8423:2015 } \\
\text { Технічні умови } \\
\text { ДСТУ 8422:2015 } \\
\text { Технічні умови }\end{array}$ & $\begin{array}{l}\text { довжина й діаметр стебел, } \\
\text { вихід лубу і його зношуваність }\end{array}$ \\
\hline 2. & треста & $\begin{array}{l}\text { довжина від прикореневої частини до } \\
\text { подільність волокна,зношуваність }\end{array}$ \\
\hline 3. & довге тіпане волокно & $\begin{array}{l}\text { ГОСТ 10379-76 } \\
\text { Технічні умови }\end{array}$ & $\begin{array}{l}\text { Розривне навантаження, лінійна } \\
\text { щільність, вміст лапи, вміст костриці, } \\
\text { вміст прядок, довжина жмені }\end{array}$ \\
\hline 4. & коротке волокно & $\begin{array}{l}\text { ГОСТ 9993-2014 } \\
\text { Міждержавний } \\
\text { стандарт }\end{array}$ & $\begin{array}{l}\text { Розривне навантаження скрученої } \\
\text { стрічечки, вміст костриці, масова } \\
\text { частка лапи }\end{array}$ \\
\hline 5. & угари & $\begin{array}{l}\text { ГОСТ 12925-77 } \\
\text { Міждержавний } \\
\text { стандарт }\end{array}$ & $\begin{array}{l}\text { масова частка, \%: костриці, костриці } \\
\text { та паклі, пуху та пилу, паклі, } \\
\text { сторонніх домішок }\end{array}$ \\
\hline
\end{tabular}


Таблиця 4. Властивості насіння та харчових продуктів з конопель, шо регламентовані національними нормативними документами

\begin{tabular}{|c|c|c|c|}
\hline $\begin{array}{l}\text { № } \\
\text { 3/ח }\end{array}$ & $\begin{array}{c}\text { Найменування } \\
\text { сировинного матеріалу }\end{array}$ & $\begin{array}{l}\text { Нормативні } \\
\text { документи }\end{array}$ & Показники якості \\
\hline 1. & посівний матеріал & $\begin{array}{l}\text { ДСТУ 2240-93 } \\
\text { Технічні умови }\end{array}$ & $\begin{array}{l}\text { Сортова чистота або типовість; } \\
\text { вміст насіння: основної культури, } \\
\text { інших культур, бур'янів; схожість; } \\
\text { вологість }\end{array}$ \\
\hline 2. & $\begin{array}{l}\text { насіння конопель } \\
\text { обрушене }\end{array}$ & $\begin{array}{l}\text { ТУ У 10.4-39224310- } \\
\text { 003:2019 }\end{array}$ & $\begin{array}{l}\text { масова частка вологи, масова } \\
\text { частка сміттєвих домішок, кислотне } \\
\text { число, вміст шкідників, масова } \\
\text { частка олії, масова частка золи, } \\
\text { масова частка клітковини, масова } \\
\text { частка протеїну, масова частка } \\
\text { мінеральних речовин }\end{array}$ \\
\hline 3. & $\begin{array}{l}\text { борошно, висівки, } \\
\text { протеїн конопляний }\end{array}$ & $\begin{array}{l}\text { TУ У 10.4-39224310- } \\
\text { 002:2019 }\end{array}$ & $\begin{array}{l}\text { Масова частка вологи, масова } \\
\text { частка протеїну, масова частка олії, } \\
\text { масова частка золи, } \\
\text { масова частка клітковини, } \\
\text { зараженість шкідниками }\end{array}$ \\
\hline 4. & $\begin{array}{l}\text { сировина для } \\
\text { переробної галузі }\end{array}$ & $\begin{array}{l}\text { ГОСТ 9158-76 } \\
\text { Міждержавний } \\
\text { стандарт }\end{array}$ & $\begin{array}{l}\text { вологість, чистота, зараженість } \\
\text { шкідниками хлібних запасів }\end{array}$ \\
\hline 5. & олія конопляна & $\begin{array}{l}\text { TУ У 10.4-39224310- } \\
\text { 002:2019 }\end{array}$ & $\begin{array}{l}\text { Кислотне число, пероксидне число, } \\
\text { йодне число, вміст вологи та легких } \\
\text { речовин, вміст нежирних домішок, } \\
\text { вміст фосфоровмісних речовин, } \\
\text { вміст загальної золи, вміст } \\
\text { вітамінів }\end{array}$ \\
\hline
\end{tabular}

Наведені показники пов'язані зі споживними характеристиками конопляних волокон й продуктів харчування, але вони не відображають повною мірою безпечність виробів, їх санітарно-гігієнічні властивості та інші властивості для життєдіяльності людини.

Висновки та перспективи подальших досліджень. Тому розроблення та систематизація споживних характеристик конопляних волокон та продукції, виготовленої 3 насіння конопель $€$ нагальним завданням сьогодення, враховуючи стрімкий ріст інноваційних технологій.

Вимоги щодо якості конопляних волокон доцільно формувати і оцінювати з урахуванням впливу їх на життєдіяльність організму людини. В перспективі пропонується дослідження споживних властивостей конопляних волокон 3 
урахуванням санітарно-гігієнічних, антисептичних, фізико-хімічних властивостей енергетичної та лікувальної цінності харчових продуктів.

\section{Список використаних джерел}

1. Вирощування промислових конопель має стати частиною державної екологічної політики [електроний ресурс]. URL: https://bituk.media/specztema/poglyad-na-promyslovikonopli-cherez-pryzmu-derzhavnoyi-ekologichnoyi-polityky-1-2/.

2. Маринченко I.О. Розроблення ресурсозберігаючої технології одержання трести конопель: дисертація кандидата технічних наук: 05.07.15 / Маринченко Ігор Олексійович. Суми, 2015. - $186 \mathrm{c}$.

3. Ляліна Н.П. Первинна переробка соломи конопель 3 метою одержання целюлозовмісних матеріалів: дисертація кандидата технічних наук: 05.08.03 / Ляліна Наталя Петрівна. Херсон, 2003. 134 с.

4. Коропченко С.П. Розробка технологічного процесу виділення лубу конопель: дисертація кандидата технічних наук: 09.00.07 / Коропченко Сергій Петрович. Херсон, 2007. $137 \mathrm{c}$.

5. Безбабченко А.В. Исследование переработки технической конопли после зернового комбайна в однотипную и штапелированную пеньку / Международ. науч.-практ. конф. «Инновационные разработки производства и переработки лубяных культур», 19-20 мая 2016г.: тезисы доп., Тверь: ФГБНУ ВНИИМЛ, 2016. С. 278-285.

6. Мохер Ю.В., Баранник В.Г. Актуальні проблеми відродження коноплярства в Україні. Біологія, вирощування, збирання та первинна переробка льону $і$ конопель: зб. Наук. праць. Вип. 3. Глухів: Інститут луб'яних культур УААН, 2004. С. 177-192.

7. Новиков, Э.В., Проталинский С.Е., Безбабченко А.В. Исследование технологий переработки конопли в однотипное волокно различных характеристик. Изв. Вузов. Технология текстильной промышленности. 2014. №6. С. 42-46.

8. Пашин Е.Л. Совершенствование технологии уборки и переработки конопли. Вестник ВНИИ по переработки лубяных культур. Кострома: Изд-во ВНИИЛК, 2007. №3. С. 76-82.

9. Разин С.Н. Теоретические основы совершенствования механической модификации льна : Монография. Кострома: КГТУ, 2005. 156 с.

10. Дорофеев В.В. Разработка и исследование технологии получения модифицированных лубяных волокон на базе ударно-волнового воздействия: дисс.... Наук: спец. 05.19.02 Технология и первичная обработка текстильних материалов и сырья. Москва, 2014. $192 \mathrm{c}$.

11. Innovative Technologies in the Hemp Industry URL: https: // cannabiz.media/10innovative-technologies-in-the-hemp-industry/.

12. Applications of hemp in textiles, paper industry, insulation and building materials, horticulture, animal nutrition, food and beverages, nutraceuticals, cosmetics and hygiene, medicine, agrochemistry, energy production and environment: a review URL: https://link.springer.com/article/10.1007/s10311-020-01029-2. 
13. Сучасний ассортимент товарів із технічних конопель URL: http://journals.khnu.km.ua/vestnik/pdf/tech/pdfbase/2018/2018_3/jrn/pdf/23.pdf.

14. Вирощування технічної коноплі варто дорегулювати. URL: https://www.epravda.com.ua/columns/2020/10/21/666458/.

15. Анализ рынка технической конопли, ее семян и продуктов переработки из нее в Украине. 2020 год URL: https://pro-consulting.ua/issledovanie-rynka/analiz-rynka-tehnicheskojkonopli-ee-semyan-i-produktov-pererabotki-iz-nee-v-ukraine-2020-god.

16. Бойко Г.А., Тіхосова Г.А., Кутасов А.В. Технічні коноплі: перспективи розвитку в Україні. Товари і ринки, 2018. №1. С. 110-120.

17. Не смешно, но выгодно. Станет ли конопля украинской «нефтью». URL: https://www.dsnews.ua/economics/ne-smeshno-no-vygodno-kak-konoplya-stanovitsya-ukrainskoy25062020220000.

18. Сова Н.А. Технологія комплексної переробки насіння промислових конопель: автореф. дисертація канд. техн. наук: спец. 05.18.02 - Технологія зернових, бобових, круп’яних продуктів і комбікормів, олійних і луб'яних культур. Херсон, 2019. 28 с.

19. Стандартизація у галузі коноплярства: стан та перспективи. URL: http://ibcuaas.at.ua/TEMP/ZBIRNIK/Zbirnik_2/Mokher_.pdf.

\section{References}

1. Vyroshchuvannia promyslovykh konopel maie staty chastynoiu derzhavnoi ekolohichnoi polityky [The cultivation of industrial hemp should become part of state environmental policy]. URL: https://bituk.media/specztema/poglyad-na-promyslovi-konopli-cherez-pryzmu-derzhavnoyiekologichnoyi-polityky-1-2/.

2. Marynchenko I.O.(2015). Rozroblennia resursozberihaiuchoi tekhnolohii oderzhannia tresty konopel: dys. Kandydata tekhnichnykh nauk: 05.07.15[Development of resource-saving technology for obtaining hemp trusts: dis. Candidate of technical sciences]. Sumy, 2015. $186 \mathrm{~s}$.

3. Lialina N.P.(2003). Pervynna pererobka solomy beznarkotychnykh konopel z metoiu oderzhannia tseliulozovmisnykh materialiv: dys. Kandydata tekhnichnykh nauk: 05.08.03[Primary processing of straw of non-narcotic hemp for the purpose of receiving cellulose-containing materials: dis. Candidate of technical sciences]. Kherson, 2003. $134 \mathrm{s.}$

4. Koropchenko S.P. (2007). Rozrobka tekhnolohichnoho protsesu vydilennia lubu konopel: dys. Kandydata tekhnichnykh nauk: 09.00.07[Development of technological process of hemp bast extraction: dis. Candidate of Technical Sciences]. Kherson, 2007. 137 s.

5. Bezbabchenko A.V. (2016). Yssledovanye pererabotky tekhnycheskoi konoply posle zernovoho kombaina $\mathrm{v}$ odnotypnuiu y shtapelyrovannuiu penku [Investigation of the processing of industrial hemp after a grain harvester into the same type and chopped hemp]. International. Scientific-practical conf. «Innovative developments in the production and processing of bast crops», 19-20 may 2016. Tver: FHBNU VNYYML, 2016. S. 278-285.

6. Mokher Yu.V., Barannyk V.H. (2004). Aktualni problemy vidrodzhennia konopliarstva v Ukraini [Current problems of hemp revival in Ukraine.]. Biolohiia, vyroshchuvannia, zbyrannia ta pervynna pererobka lonu i konopel: $z b$. Nauk. Prats. [Biology, cultivation, harvesting and primary processing of flax and hemp] Vyp. 3. Hlukhiv: Instytut lubianykh kultur UAAN, 2004. S. 177-192. 
7. Novykov, Э.V., Protalynskyi S.E., Bezbabchenko A.V.(2014). Yssledovanye tekhnolohyi pererabotky konoply $\mathrm{v}$ odnotypnoe volokno razlychnыkh kharakterystyk [Research of hemp processing technologies into the same type of fiber of different characteristics]. Yzv. Vuzov. Tekhnolohyia tekstylnoi promshlennosty [Izv. Universities. Textile industry technology]. 2014. №6. S. 42-46.

8. Pashyn E.L.(2007). Sovershenstvovanye tekhnolohyy uborky y pererabotky konoply [Improving the technology of harvesting and processing hemp]. Vestnyk VNYY po pererabotky lubiankh kultur VNII bulletin for processing bast crops. Kostroma: Yzd-vo VNYYLK, 2007. №3. S. 76-82.

9. Razyn S.N. Teoretycheskye osnov sovershenstvovanyia mekhanycheskoi modyfykatsyy lna [Theoretical foundations for improving the mechanical modification of flax]: Monograph. Kostroma: KSTU, 2005.156 p.

10. Dorofeev V.V.(2014). Development and research of the technology for obtaining modified bast fibers based on shock-wave action: diss... cand. Tech. Sciences: spec. 05.19.02 Technology and primary processing of textile materials and raw. Moskva, 2014. $192 \mathrm{~s}$.

11. Innovative Technologies in the Hemp Industry. URL: https: // cannabiz.media/10innovative-technologies-in-the-hemp-industry/.

12. Applications of hemp in textiles, paper industry, insulation and building materials, horticulture, animal nutrition, food and beverages, nutraceuticals, cosmetics and hygiene, medicine, agrochemistry, energy production and environment: a review. URL: https://link.springer.com/article/10.1007/s10311-020-01029-2.

13. Modern range of technical hemp products. URL: http://journals.khnu.km.ua/vestnik/pdf/tech/pdfbase/2018/2018_3/jrn/pdf/23.pdf.

14. The cultivation of technical hemp should be regulated. URL: https://www.epravda.com.ua/columns/2020/10/21/666458/.

15. Analysis of the market for technical hemp, its seeds and processed products from it in Ukraine. 2020 year. URL: https://pro-consulting.ua/issledovanie-rynka/analiz-rynka-tehnicheskojkonopli-ee-semyan-i-produktov-pererabotki-iz-nee-v-ukraine-2020-god.

16. H.A. Boiko, Tikhosova H.A., A.V. Kutasov (2018). Tekhnichni konopli: perspektyvy rozvytku v Ukraini [Technical hemp: prospects for development in Ukraine]. Tovary i rynky, 2018. №1. S. 110-120.

17. Ne smeshno...... URL: https://www.dsnews.ua/economics/ne-smeshno-no-vygodno-kakkonoplya-stanovitsya-ukrainskoy-25062020220000.

18. Sova N.A. Technology of complex processing of seeds of industrial hemp: author's ref. dis. ... Cand. Tech. Science: special. 05.18.02 - Technology of grain, legumes, cereals and animal feeds, oilseeds and bast crops. Kherson, 2019. 28 p.

19. Standardization in the field of cannabis: status and prospects. URL: http://ibcuaas.at.ua/TEMP/ZBIRNIK/Zbirnik_2/Mokher_.pdf.

Goal. The aim of the work is to study the consumer characteristics of hemp products obtained by innovative technologies. The development of new methods of obtaining hemp products using innovative technologies is given considerable attention all over the world. The paper proved that 
the expansion of the system for assessing the quality of consumer characteristics of new products obtained from hemp stems and seeds, obtained by innovative technologies is an important question.

Methodology. During the study, the methods provided by the current standards were used. A review of sources of technical and commodity literature was carried out using information and analytical methods of comparative and system analysis.

Results. The article presents an analysis of the current state of the processing of hemp stems and seeds in different countries of the world. The analysis of the quality of the products obtained was carried out using various technologies. It has been established that in Ukraine, despite the increase in the technological activity of hemp fiber and seed producers, there is almost no commodity assessment of the qualitative properties of the new products obtained, which affect the human body. The paper provides an assessment of the commodity characteristics of hemp products on the basis of the existing regulatory framework and identifies the tasks to expand this assessment depending on the functional purpose of innovative products.

Special attention should be paid to the study of sanitary and hygienic properties, antiseptic characteristics of hemp products, since there are no regulatory documents for their determination. All of this is the basis for further research. In the future, consumer characteristics will be investigated, taking into account the sanitary and hygienic, antiseptic, physical and mechanical properties and the energy and medicinal value of hemp food products.

Scientific novelty. The paper highlights the existing system for assessing the quality of hemp products based on the outdated regulatory framework. The quality indicators used for the modern characterization of hemp products do not reflect the functional purpose of innovative products made from hemp stems and seeds, and therefore cannot be used to determine their competitiveness in the domestic and world markets. Therefore, on the basis of the analysis, the work proves the need to expand the system of quality indicators of hemp products, taking into account their effect on the human body, that is, sanitary and hygienic, antiseptic, biological properties, as well as the energy and medicinal value of hemp foods.

Practical significance. The proposed studies can be used to create regulatory documents for hemp fibers obtained using innovative technologies. The obtained research results can be used to identify counterfeit hemp products crossing the border of Ukraine.

Keywords. Hemp products, innovative technologies, consumer properties, sanitary and hygienic properties, antiseptic properties.

Стаття рекомендована до друку доктором технічних наук, професором ХНТУ Чурсіною Л.А. Дата надходженняв редакиію 13.01.2021 p. 